ISSN 0258-7122

Bangladesh J. Agril. Res. 39(2): 337-350, June 2014

\title{
DEVELOPMENT OF SUITABLE PACKAGE FOR TRANSPORTATION OF GUAVA (Psidium guajava L.)
}

\author{
M. N. AMIN ${ }^{1}$, M. A. HOSSAIN ${ }^{2}$, M. S. MIAH ${ }^{3}$ \\ M. S. HASSAN ${ }^{4}$ AND M. A. HOQUE 5
}

\begin{abstract}
Guava (Psidium guajava L.) is a perishable and climacteric fruit. The peel surface of guava is soft. During transportation, guava surface is rupture lack of proper packaging. Two types of corrugated fibre board (CFB) cartons of 7 and 5 ply and one type of wooden box were designed and fabricated for transportation of guava in Farm Machinery and Postharvest Process Engineering (FMPE) Division, Bangladesh Agricultural Research Institute, Gazipur in 2013. The dimensions of the cartons were $513 \times 300 \times 240 \mathrm{~mm}$ and $400 \times 300 \times 300 \mathrm{~mm}$. The 7 ply cartons of both the size were found better than those of 5 ply cartons in terms of static load bearing capacity. The carton of 513 × $300 \times 240 \mathrm{~mm}$ was better than that of second one. The holding capacities of these cartons were about $18-20 \mathrm{~kg}$ of guava. The static load bearing capacities of both the cartons of 7 and 5 ply cartons were 90 and $70 \mathrm{~kg}$, respectively. Green matured guava was harvested, sorted and packed in different packages, such as bamboo basket, wooden box, plastic crate, and CFB cartons. They were transported from Sharupkhati of Barisal to Gazipur by a track. Then the guava packages were opened in FMPE Division, BARI, Gazipur and stored at ambient temperature $\left(28.8 \pm 2{ }^{\circ} \mathrm{C}\right)$ and humidity $(87 \pm 2 \%)$ for 8 days. The highest shelf-life of guava was found in wooden box without wrapping and the lowest shelf-life was in CFB cartons with polyethylene $(0.05 \mathrm{~mm})$ having $2 \%$ perforation. Wooden box was found suitable as packaging material for transportation of guava in terms of freshness, shelf-life, and packaging cost. Packaging cost of CFB cartons was higher followed by that of plastic crate, wooden box, and bamboo basket. Packaging costs of plastic crate and wooden box were cheaper than those of CFB cartons and bamboo basket. Plastic crate and wooden box should be used for local market to transport the fruits. CFB carton may be used for export market or supper market.
\end{abstract}

Keywords: Development, suitable package, transportation.

\section{Introduction}

Guava (Psidium guajava L.) is considered one of the most important fruit crops throughout the tropical and subtropical countries with high consumer demand worldwide. In Bangladesh, guava is produced 0.27 million tonnes annually (BBS, 2011). Higher transportation loss and quality losses of guava was observed in the

${ }^{1 \& 5}$ Senior Scientific Officer, ${ }^{2}$ Pricipal Scientific Officer, ${ }^{3}$ Scientific Officer and ${ }^{4}$ Chief Scientific Officer, Farm Machinery and Postharvest Process Engineering Division, Bangladseh Agricultural Research Institute (BARI), Gazipur, Bangladesh. 
market. Lack of proper package, the guava surface was observed to rupture. Due to poor quality of the fruit, market price becomes low. Packaging systems are very important components of the postharvest chain of fresh horticultural crops. Packaging is made of different sizes, shapes, and materials depending on the type of product and purpose of their use. Importance of packages is increasing for direct marketing to consumers and they are made of different materials, such as polyethylene, plastic, paper, and fiberboard carton. They have several advantages including reduce damage and handling to the produce, increased marketing and profits and more convenience to the consumers.

Basket is commonly used in developing countries, especially in Asia. Wooden boxes are not commonly used in Bangladesh, but several crops from India are imported in these packages. Fiberboard boxes are the common packages used for the export market. The use of the plastic film and bags for the packaging of the fresh horticultural crops is increasing all over the world (Yahia and AitOubahou, 2001). Approximately 30-50\% fruits go waste during postharvest handling, storage, and ripening (Lashley, 1984).

Perforated polyethylene films are commonly used to minimize weight loss, reduce abrasion, damage and delay fruit ripening (Wills et al., 1998; Elkashif et al., 2005). Packing the fruits in carton boxes lined with perforated or sealed polyethylene films reduced the weight loss by $4.5 \%$ and $9.1 \%$, respectively, compared to the control fruits (Elkashif et al., 2005; Elamine, 2006).

Lashley (1984) reported the methods of reducing postharvest losses through genetic control of storage life, field and postharvest treatment viz., hot water treatments, wooden box, plastic crate, corrugated fiberboard packaging, and plastic film for atmospheric modification. Han and Park (2007) reported that ventilation surface area occupied by the holes was approximately 2 percent of the total surface area of the side faces of the boxes. The appropriate shape of ventilation hole is a vertical oblong that is symmetrically located at about the centre of the front and rear faces. Hand holes should be located higher than the centre of the side face with the appropriate horizontal oblong shape. It was also found that an increase in the radius of curvature at both ends of the hand hole provided better stress relaxation and lower stress. Minimum decrease in box compression strength was achieved when the length of the holes should be less than $1 / 4$ of the depth of the box; width the length ratio of the holes should be 1/3.5-1/2.5; and even numbered holes should be located symmetrically. There is no suitable transport packaging container for guava in our country. The study is given an emphasis that develops suitable transportation packaging of guava. 


\section{Materials and Method}

Two types corrugated fibre board (CFB) cartons and one type of wooden box were designed and developed for transportation of guava in Farm Machinery and Postharvest Process Engineering Division, Bangladesh Agricultural Research Institute, Joydebpur, Gazipur in 2013.

The corrugated fibre board carton and wooden box are designed with the following consideration

Size of CFB carton and wooden box for guava $=18-20 \mathrm{~kg}$

Size of fruit of guava $=100-110 \mathrm{~g}$

\section{Development of the corrugated fibre board (CFB) carton}

\section{For $513 \times 300 \times 240 \mathrm{~mm}$ carton}

Number of fruits of guava contain in carton $=180-200$

Length of carton $=$ maximum diameter of guava $\times 9$ fruits place one layer horizontally

$$
=57 \mathrm{~mm} \times 9=513 \mathrm{~mm}
$$

Width of carton $=$ maximum diameter of fruit $\mathrm{x} 5$ fruits place one layer $=60 \mathrm{~mm}$ x $5=300 \mathrm{~mm}$

Height of carton $=$ maximum diameter of fruit $\mathrm{x} 4$ fruits place one layer $=60 \mathrm{~mm}$ $\mathrm{x} 4=240 \mathrm{~mm}$

\section{For $400 \times 300 \times 300 \mathrm{~mm}$ carton}

Number of fruits of guava contain in carton=180-200

Length of carton $=$ maximum diameter of guava $\times 7$ fruits place one layer horizontally

$$
=57 \mathrm{~mm} \times 7=400 \mathrm{~mm}
$$

Width of carton $=$ maximum diameter of fruit $\mathrm{x} 5$ fruits place one layer $=60 \mathrm{~mm}$

$$
\text { x } 5=300 \mathrm{~mm}
$$

Height of carton $=$ maximum diameter of fruit $x 5$ fruits place one layer $=60 \mathrm{~mm}$ x $5=300 \mathrm{~mm}$

\section{For wooden box $(513 \times 300 \times 240 \mathrm{~mm})$}

Wooden box was designed and developed as designed of CFB carton of $513 \times 300 \times 240 \mathrm{~mm}$. It was made of light in weight and low cost wood. 
Specifications of CFB cartons, wooden box, plastic crate, and bamboo basket are shown in Table 1. The top, front and side views of the CFB cartons and wooden box are presented in Fig. 1. Isometric view of CFB carton and wooden box are illustrated in Fig. 2. Structural view of the 7 ply of the CFB carton is shown in Fig. 3. The load bearing capacities of the cartons were measured manually (Fig. 4). Green matured guavas of variety Sharupkathi local were harvested from a guava orchard at Sharupkathi in Barisal on 21 July 2013. They were sorted, graded, and packed in bamboo basket, plastic crate, wooden box, and CFB cartons. They were transported from Sharupkati to Gazipur by a track of 3 tonnes. Percentage of green, ripe, and damage of guava was recorded 72 hours after harvesting. Ripe guavas were measured regarding the yellow colour and softness of guavas. The damage of the guavas was observed on the basis of rupture on peel surface of guava. Guava samples were stored at ambient temperature $\left(28.8 \pm 2{ }^{\circ} \mathrm{C}\right)$ and humidity $(87 \pm 2 \%)$ for 8 days. Shelf-life and colour parameters of guava peel were recorded. The experimental design was CRD with the following treatments. All the treatments were replicated thrice. The data were statistically analyzed using the software SPSS 17.

Table 1. Specifications of CFB cartons, wooden box, plastic crate and bamboo basket.

\begin{tabular}{l|c|c|c|c|c}
\hline Packages & $\begin{array}{c}\text { Dimension } \\
(\mathrm{mm})\end{array}$ & No. of ply & $\begin{array}{c}\text { Holding } \\
\text { capacity } \\
(\mathrm{kg})\end{array}$ & $\begin{array}{c}\text { Wall } \\
\text { thickness } \\
(\mathrm{mm})\end{array}$ & $\begin{array}{c}\text { Weight } \\
(\mathrm{kg})\end{array}$ \\
\hline & $400 \times 300 \times 300$ & 7 & $18-20$ & 5 & 1.136 \\
CFB Carton & $513 \times 300 \times 240$ & 7 & $18-20$ & 5 & 1.208 \\
& $400 \times 300 \times 300$ & 5 & $18-20$ & 4 & 0.825 \\
Wooden box & $513 \times 300 \times 240$ & 5 & $18-20$ & 4 & 0.800 \\
Plastic crate & $513 \times 300 \times 240$ & - & $18-20$ & & 3.20 \\
Bamboo basket & $540 \times 355 \times 290$ & - & $20-22$ & & 1.77 \\
\hline
\end{tabular}



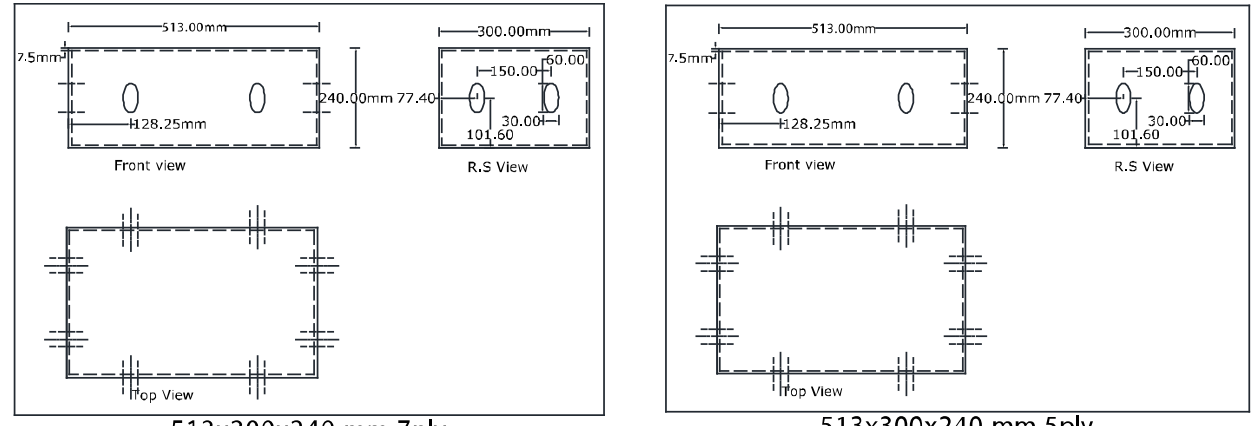

$513 \times 300 \times 240 \mathrm{~mm}, 7$ ply

$513 \times 300 \times 240 \mathrm{~mm}, 5$ ply

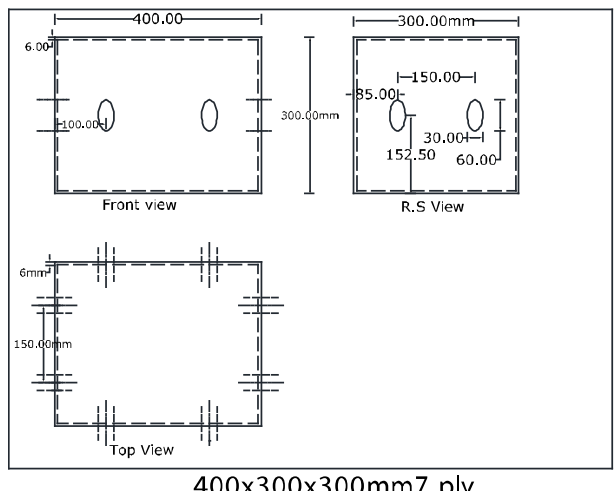

$\mathrm{C}$

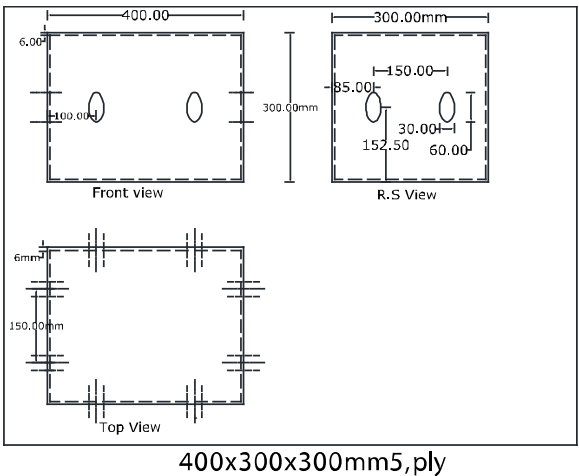

D

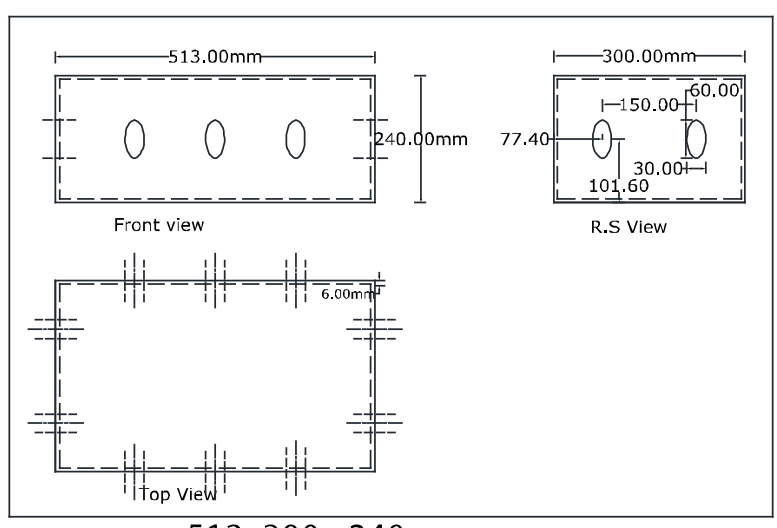

$513 \times 300 \times 240 \mathrm{~mm}$

E Wooden box

Fig. 1. Top, front and right side views of CFB cartons (a-d) and wooden (e) box. 

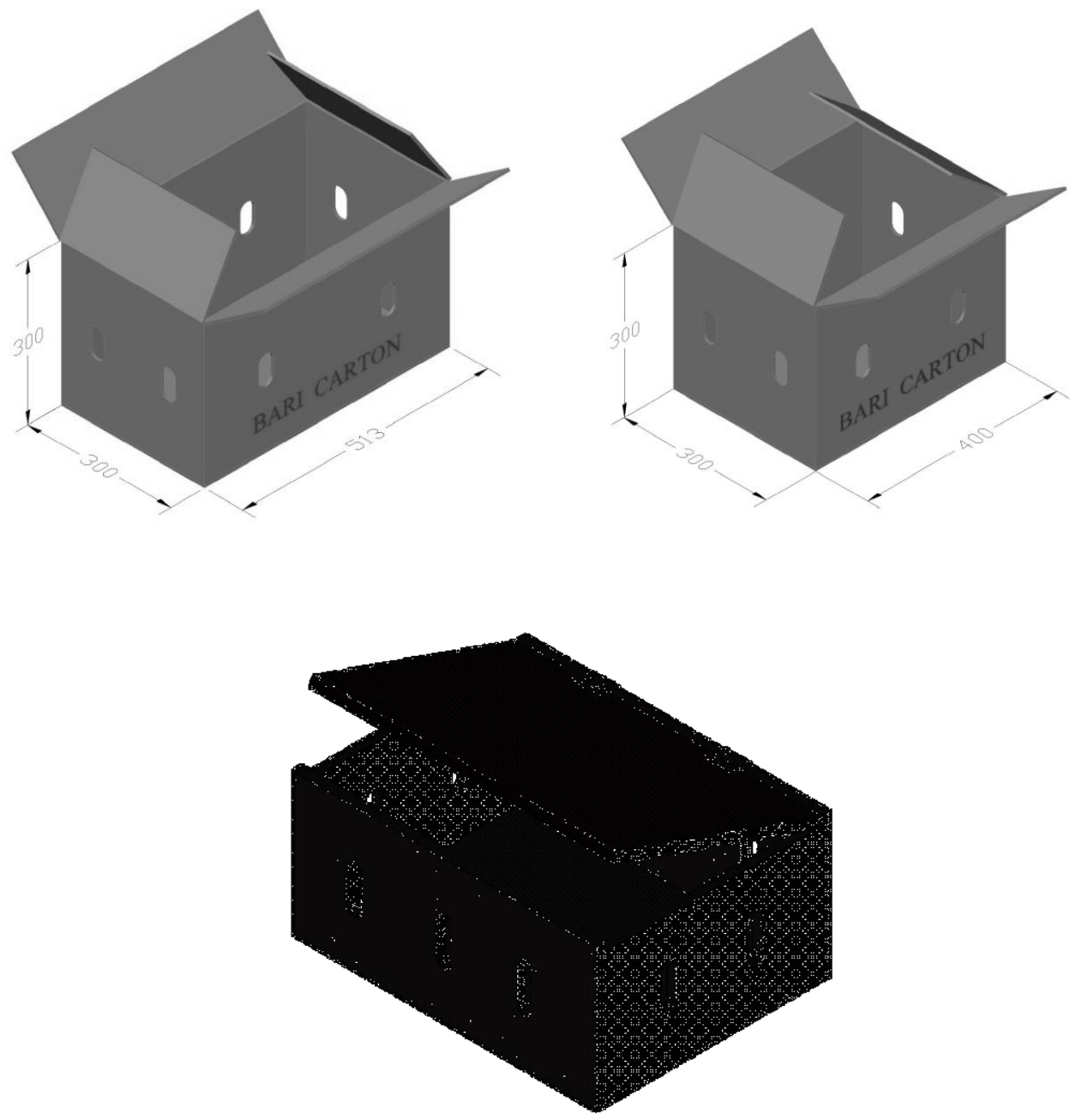

Wooden box

Fig. 2. Isometric view of the cartons and wooden box.

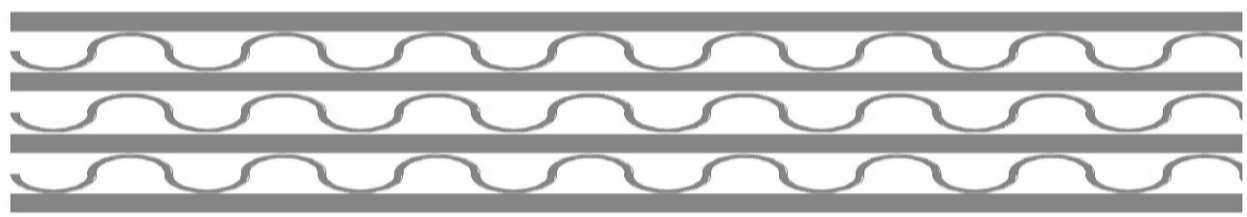

Fig. 3 Structural view of the 7 ply of the CFB carton. 

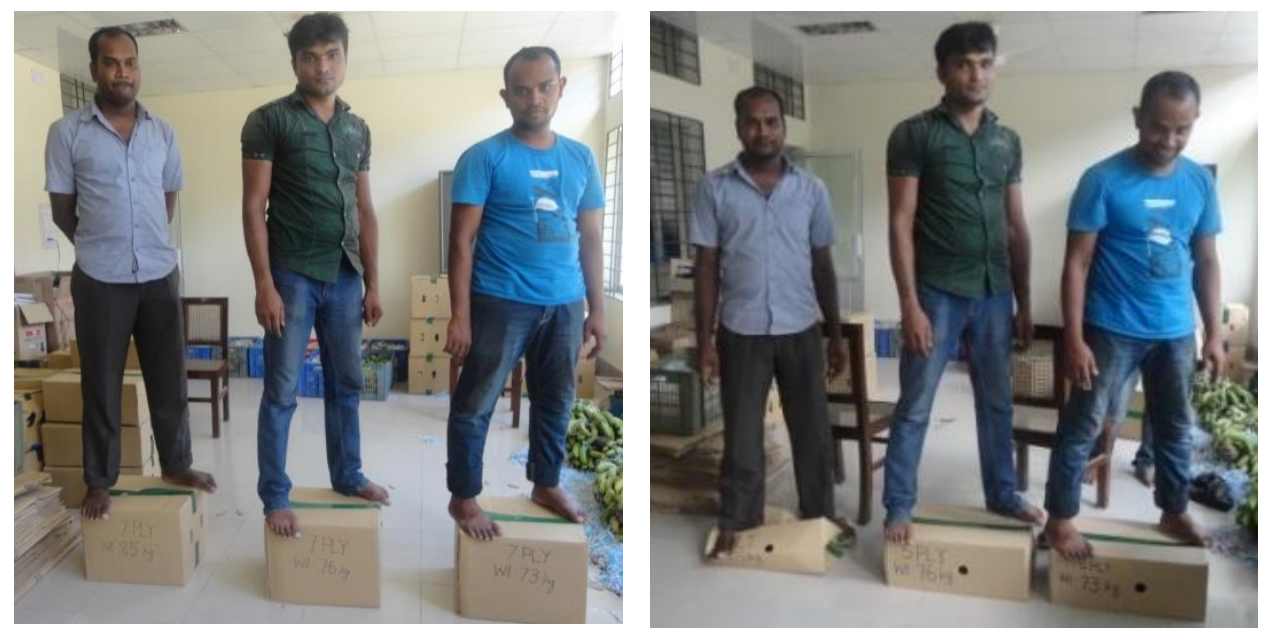

Fig. 4. Measuring the static load bearing capacity of the carton.

\section{Treatments}

$\mathrm{T}_{1}=$ bamboo basket (control)

$\mathrm{T}_{2}=$ Plastic crate with polyethylene $(0.05 \mathrm{~cm})$ having $2 \%$ perforation

$\mathrm{T}_{3}=$ Plastic crate wrapping with paper

$\mathrm{T}_{4}=$ Plastic crate without wrapping

$\mathrm{T}_{5}=$ Wooden box with polyethylene $(0.05 \mathrm{~cm})$ having $2 \%$ perforation

$\mathrm{T}_{6}=$ Wooden box wrapping with paper

$\mathrm{T}_{7}=$ Wooden box without wrapping

$\mathrm{T}_{8}=\mathrm{CFB}$ of $513 \times 300 \times 240,7 \mathrm{ply}$, with polyethylene $(0.05 \mathrm{~cm})$ having $2 \%$ perforation

$\mathrm{T}_{9}=\mathrm{CFB}$ of $513 \times 300 \times 240,7$ ply, wrapping with paper

$\mathrm{T}_{10}=\mathrm{CFB}$ of $513 \times 300 \times 240,7$ ply, without wrapping

$\mathrm{T}_{11}=\mathrm{CFB}$ of $513 \times 300 \times 240,5 \mathrm{ply}$, with polyethylene $(0.05 \mathrm{~cm})$ having $2 \%$ perforation

$\mathrm{T}_{12}=\mathrm{CFB}$ of $513 \times 300 \times 240,5$ ply, wrapping with paper

$\mathrm{T}_{13}=\mathrm{CFB}$ of $513 \times 300 \times 240,5$ ply, without wrapping

$\mathrm{T}_{14}=\mathrm{CFB}$ of $400 \times 300 \times 300,7 \mathrm{ply}$, with polyethylene $(0.05 \mathrm{~cm})$ having $2 \%$ perforation

$\mathrm{T}_{15}=\mathrm{CFB}$ of $400 \times 300 \times 300,7$ ply, wrapping with paper 
$\mathrm{T}_{16}=\mathrm{CFB} 400 \times 300 \times 300,7$ ply, without wrapping

$\mathrm{T}_{17}=\mathrm{CFB}$ of $400 \times 300 \times 300,5 \mathrm{ply}$, with polyethylene $(0.05 \mathrm{~cm})$ having $2 \%$ perforation

$\mathrm{T}_{18}=\mathrm{CFB}$ of $400 \times 300 \times 300,5$ ply, wrapping with paper

$\mathrm{T}_{19}=\mathrm{CFB}$ of $400 \times 300 \times 300,5$ ply, without wrapping

Replication:3

Design:CRD

\section{Shelf-life}

Shelf life (days) of guava fruit of each treatment was recorded during the period of storage. It was calculated from the date of harvesting to last edible stage.

\section{Physiological weight loss (PWL)}

Weight of each replication (five fruits) data was recorded at different storage periods. The physiological loss in weight was calculated on the basis of the initial weight.

The physiological weight loss was calculated as:

$$
\text { Weight } \operatorname{loss}(\%)=\frac{W_{1}-W_{2}}{W_{1}} \times 100
$$

where $\mathrm{W}_{1}=$ initial weight, $\mathrm{g}$ and $\mathrm{W}_{2}=$ final weight, $\mathrm{g}$

\section{Colour}

The peel colour of fruit was measured using a chroma meter. Colour measurements were recorded using Hunter $\mathrm{L}^{*}, \mathrm{a}^{*}$ and $\mathrm{b}^{*}$ scale (Hunter, 1975; Francis, 1980). The "L*" coordinate is a measure of lightness (white-black and ranges from no reflection $\mathrm{L}=0$ to perfect diffuse reflection $* \mathrm{~L}=100$ ), the "a*" scale ranges from negative values for green to positive values for red and the "b*" scale ranges from negative values for blue to positive values for yellow. The $\mathrm{C}^{*}$ represented the vividness of colours with values ranging from $0=$ least intense to $60=$ most intense. The $\mathrm{h}^{\circ}$ is actual or perceived colour that used to classify the kind of colour, which vary continuously from $0^{\circ}$ to $360^{\circ}$. Three readings were taken at three points on the surface of each guava and the mean values of $\mathrm{L}^{*}, \mathrm{a}^{*}$ and $\mathrm{b}^{*}$ were calculated. 


\section{Results and Discussion}

The percentage of green, ripe, and damage of guava at different packaging 72 hours after harvesting is given in Table 2. The highest green guavas were obtained from wooden box with wrapping $(52.28 \%)$ followed by bamboo basket (43.52\%), plastic crate (43.81\%), and CFB cartons (49.89\%). The lowest (37.72\%) ripen guava was found in wooden box wrapping with paper. In most cases wrapping samples were ripen quickly than non-wrapped samples. Therefore, by physical observation, wooden box with wrapping materials was found good for guava transportation. Very small amount of damage was observed for all packages. Moreover, it was observed that water condensation occurred in $2 \%$ perforation polyethylene $(0.05 \mathrm{~mm})$ for all treatments. It might be due to insufficient ventilation space of the carton. Three cartons of 5 ply were little damaged during transportation. It was also found that CFB cartons with 7 ply of both types was better than 5 ply CFB cartons in respect of load bearing capacity.

\section{Physiological weight loss (PWL)}

Effect of packaging on physiological weight of guava is shown in Fig. 5. The highest physiological weight loss of guava was found in plastic crate without wrapping followed by without wrapping of plastic crate with bamboo basket, wooden box, and CFB cartons. This might be due to higher evaporation for more open space of the plastic crate. On the other hand, the lowest physiological weight loss of guava was observed in CFB $(400 \times 300 \times 300 \mathrm{~mm}) 7$ ply cartons with polyethylene and the second lowest in CFB $(400 \times 300 \times 300 \mathrm{~mm}) 5$ ply carton with polyethylene. Moreover, the lower physiological weight loss of guava was found in all polyethylene bags $(0.05 \mathrm{~mm})$ with $2 \%$ peroration and wrapping with newspaper than that of without wrapping of guava.

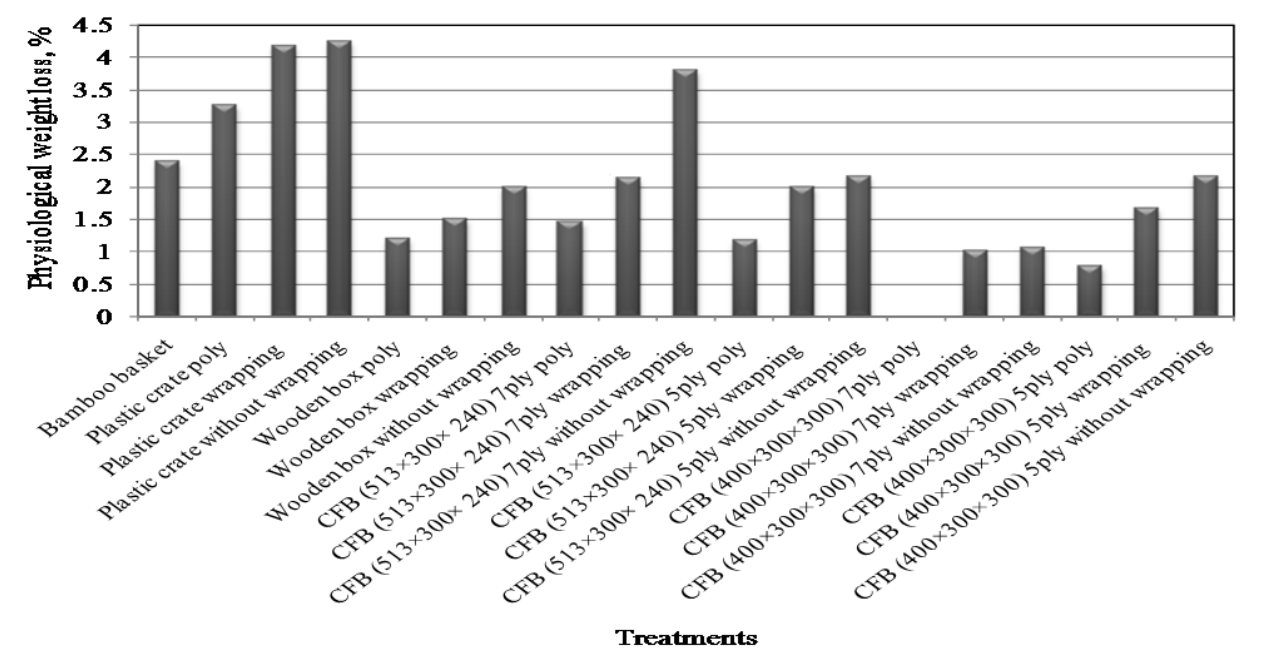

Fig. 5. Effect of packaging on physiological weight of guava. 
Table 2. The percentage of green, ripe and damage of guava at different packaging 72 hour after harvesting.

\begin{tabular}{|c|c|c|c|c|}
\hline Sl. No. & Packaging & Green, $\%$ & Ripe, \% & Damage, $\%$ \\
\hline 1 & Bamboo basket & $43.52 \mathrm{c}-\mathrm{e}$ & $45.80 \mathrm{abc}$ & $1.00 \mathrm{a}-\mathrm{e}$ \\
\hline 2 & $\begin{array}{l}\text { Plastic crate with polyethylene } \\
(0.05 \mathrm{~cm}) \text { having } 2 \% \text { perforation }\end{array}$ & $43.06 \mathrm{cde}$ & 47.69ab & $0.80 \mathrm{~b}-\mathrm{e}$ \\
\hline 3 & Plastic crate wrapping with paper & $43.81 b-e$ & $45.92 \mathrm{abc}$ & $0.79 \mathrm{cde}$ \\
\hline 4 & Plastic crate without wrapping & 43.10cde & $45.43 \mathrm{abc}$ & $1.55 \mathrm{a}$ \\
\hline 5 & $\begin{array}{l}\text { Wooden box with polyethylene } \\
(0.05 \mathrm{~cm}) \text { having } 2 \% \text { perforation }\end{array}$ & $46.58 \mathrm{a}-\mathrm{e}$ & 43.19a-f & $0.83 \mathrm{~b}-\mathrm{e}$ \\
\hline 6 & Wooden box wrapping with paper & $52.28 \mathrm{a}$ & $37.72 \mathrm{f}$ & $0.71 \mathrm{de}$ \\
\hline 7 & Wooden box without wrapping & 47.24abcd & $38.52 \mathrm{ef}$ & $0.71 \mathrm{de}$ \\
\hline 8 & $\begin{array}{l}\text { CFB } 513 \times 300 \times 240, \quad 7 \text { ply, with } \\
\text { polyethylene }(0.05 \mathrm{~cm}) \text { having } 2 \% \\
\text { perforation }\end{array}$ & 43.79b-e & $44.85 \mathrm{a}-\mathrm{d}$ & $1.52 \mathrm{a}$ \\
\hline 9 & $\begin{array}{l}\text { CFB } 513 \times 300 \times 240,7 \text { ply, wrapping } \\
\text { with paper }\end{array}$ & 45.36b-e & $44.33 \mathrm{a}-\mathrm{e}$ & $0.84 \mathrm{~b}-\mathrm{e}$ \\
\hline 10 & $\begin{array}{l}\text { CFB } 513 \times 300 \times 240,7 \text { ply, without } \\
\text { wrapping }\end{array}$ & $49.15 \mathrm{abc}$ & $40.56 \mathrm{c}-\mathrm{f}$ & $0.80 \mathrm{~b}-\mathrm{e}$ \\
\hline 11 & $\begin{array}{l}\text { CFB } 513 \times 300 \times 240,5 \text { ply, with } \\
\text { polyethylene }(0.05 \mathrm{~cm}) \text { having } 2 \% \\
\text { perforation }\end{array}$ & $49.89 \mathrm{ab}$ & 39.17def & $1.25 \mathrm{a}-\mathrm{d}$ \\
\hline 12 & $\begin{array}{l}\text { CFB 513, } 5 \text { ply, plywrapping with } \\
\text { paper }\end{array}$ & 44.30b-e & $44.49 a-e$ & $1.42 \mathrm{abc}$ \\
\hline 13 & $\begin{array}{l}\text { CFB } 513 \times 300 \times 240,5 \text { ply, without } \\
\text { wrapping }\end{array}$ & $44.89 \mathrm{~b}-\mathrm{e}$ & $43.93 \mathrm{a}-\mathrm{e}$ & $1.42 \mathrm{abc}$ \\
\hline 14 & $\begin{array}{l}\text { CFB } 400 \times 300 \times 300, \quad 7 \text { ply, with } \\
\text { polyethylene }(0.05 \mathrm{~cm}) \text { having } 2 \% \\
\text { perforation }\end{array}$ & 46.58a-e & $42.21 b-f$ & $1.44 \mathrm{ab}$ \\
\hline 15 & $\begin{array}{l}\text { CFB } 400 \times 300 \times 300,7 \text { ply, wrapping } \\
\text { with paper }\end{array}$ & 44.43b-e & $45.38 \mathrm{abc}$ & $0.65 \mathrm{de}$ \\
\hline 16 & $\begin{array}{l}\text { CFB } 400 \times 300 \times 300,7 \text { ply, without } \\
\text { wrapping }\end{array}$ & $40.54 \mathrm{e}$ & $49.25 \mathrm{a}$ & $0.65 \mathrm{de}$ \\
\hline 17 & $\begin{array}{lllr}\text { CFB } 400 \times 300 \times 300, & 5 & \text { ply, } & \text { with } \\
\text { polyethylene } & (0.05 \mathrm{~cm}) & \text { having } & 2 \% \\
\text { perforation } & & & \end{array}$ & 46.26b-e & $43.51 \mathrm{a}-\mathrm{f}$ & $0.84 \mathrm{~b}-\mathrm{e}$ \\
\hline 18 & $\begin{array}{l}\text { CFB } 400 \times 300 \times 300,5 \text { ply,wrapping } \\
\text { with paper }\end{array}$ & $42.69 \mathrm{de}$ & 47.29ab & $0.56 \mathrm{e}$ \\
\hline 19 & $\begin{array}{l}\text { CFB } 400 \times 300 \times 300,5 \text { ply, without } \\
\text { wrapping }\end{array}$ & 46.96a-d & $42.12 b-f$ & $1.26 \mathrm{a}-\mathrm{d}$ \\
\hline $\mathrm{CV}(\%)$ & & 8.32 & 9.29 & 42.52 \\
\hline
\end{tabular}




\section{Shelf-life}

Effect of packaging on shelf-life of guava is shown in Fig. 6. The highest shelflife of guava was found in wooden box with wrapping newspaper followed by other treatments and the second highest was found in CFB $(513 \times 300 \times 240 \mathrm{~mm}) 7$ ply without news paper and same size of 5 ply carton with polyethylene. It might be due to generate lower temperature inside the box for better insulating packaging materials. The lowest shelf-life of guava was found in corrugated fibre board carton with polyethylene having $2 \%$ perforation followed by other packaging treatments. Furthermore, shelf-life of guava was higher in wrapping with newspaper than polyethylene with $2 \%$ and without wrapping.
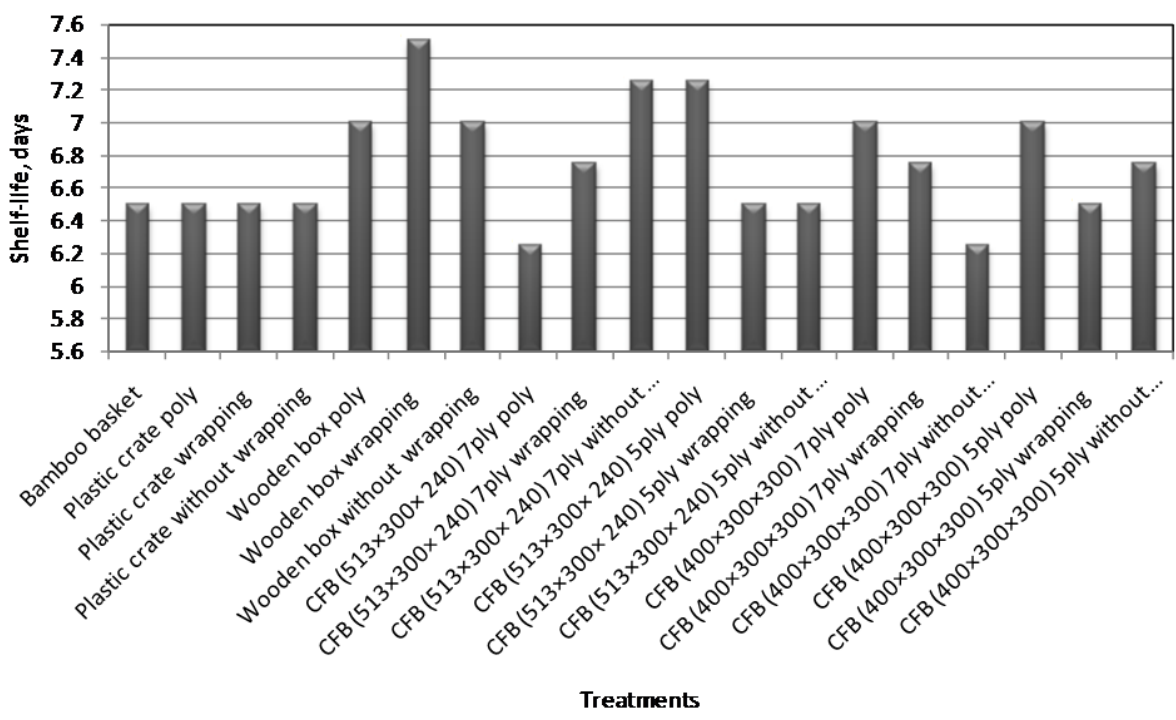

Fig. 6. Effect of packaging on shelf-life of guava.

\section{Colour parameters}

Effect of packaging treatments on colour parameters of $a^{*}$ and $\mathrm{L}^{*}$ of guava is presented in Fig. 7 and 8. The highest $a^{*}$ of guava was found in plastic crate with polyethylene followed by other packaging treatments (Fig. 7). Results indicated that colour of guava in plastic crate with polyethylene was more green. On the other hand, higher green colour observed in without wrapping of all treatments than that of wrapping treatments. The highest brightness of guava was found in wooden box with wrapping newspaper followed by bamboo basket, plastic crate and CFB cartons (Fig. 8). Chroma increased and hue angle decreased of guava of all treatments with the increase of storage period. 


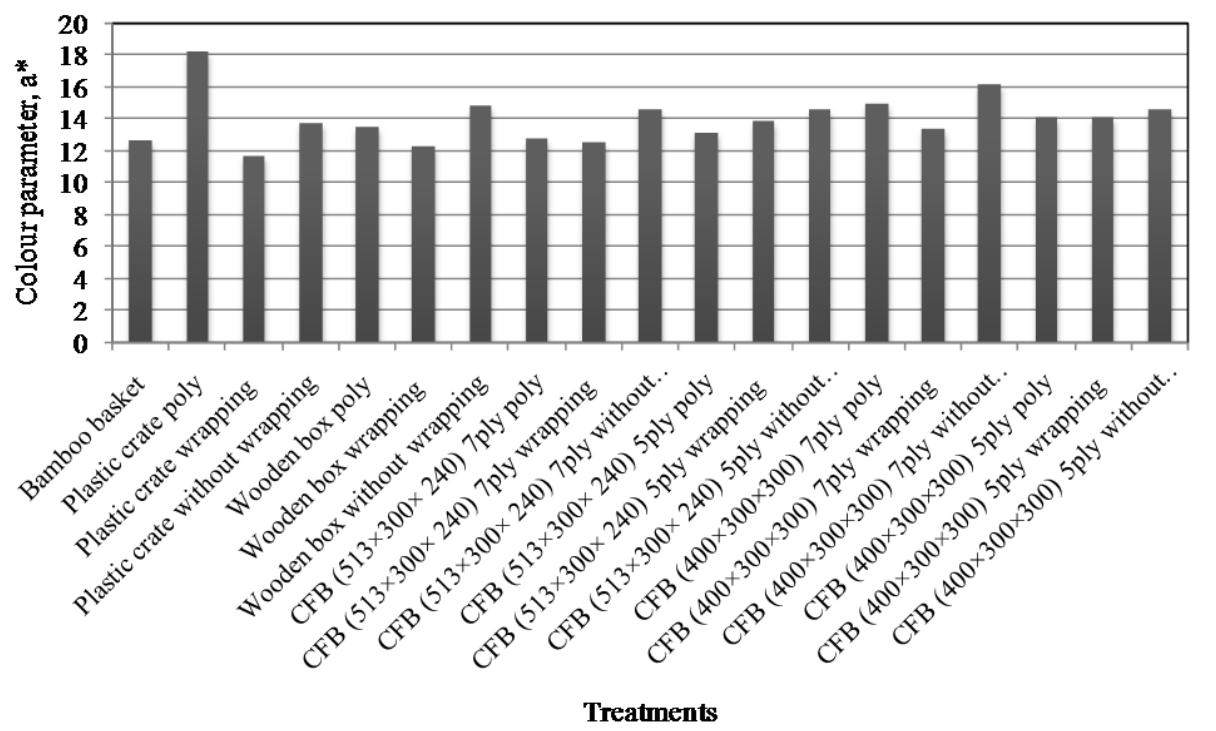

Fig.7. Effect of packaging treatments on colour parameters of a*of guava.

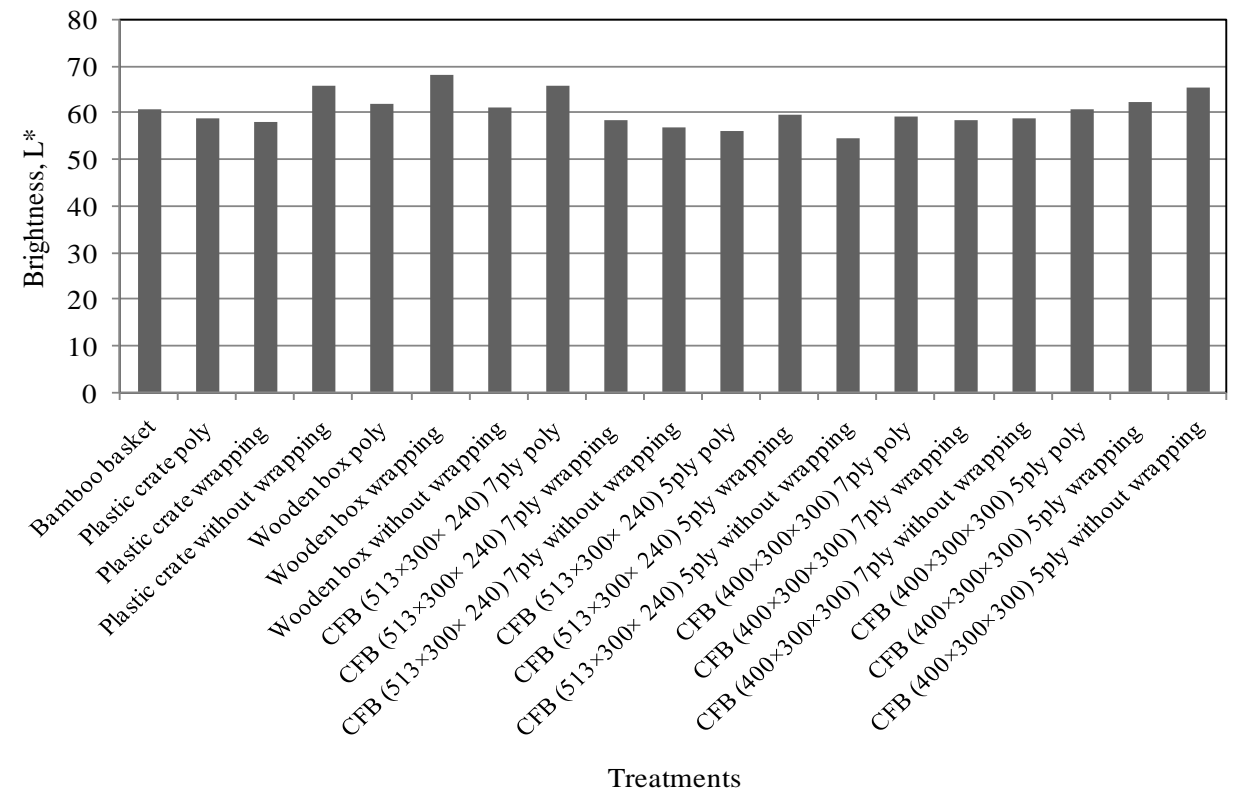

Fig.8. Effect of treatments on brightness $\left(L^{*}\right)$ of guava.

\section{Cost of different packages}

Characteristics and costs of different packages for transportation of guava are given in Table 3. Weight of packages depends on construction materials. Weight 
of wooden box $(2.8 \mathrm{~kg})$ was the highest among all other types of packages but guava holding capacity was same. The life of wooden box is 2 years and it can be used 30 times for transportation of guava. The lowest weight was for CFB cartons but it can be used only one time. The plastic crate weighed $1.77 \mathrm{~kg}$ which is lower than wooden box. Plastic crate can be used many times as 60 times in its 3 years life. The bamboo basket had the highest guava holding capacity but it can be used 3 times in its 1 year life. Considering the guava holding capacity and frequency of uses, the lowest cost was required for plastic crate followed by wooden box and bamboo basket. The highest cost was spent for CFB carton due to single time use.

Table 3. Characteristics and costs of different packages for guava.

\begin{tabular}{|c|c|c|c|c|c|c|c|}
\hline Package & $\begin{array}{c}\text { Capacity } \\
(\mathrm{kg})\end{array}$ & $\begin{array}{l}\text { Price } \\
\text { (Tk.) }\end{array}$ & $\begin{array}{c}\text { Expecte } \\
\text { d life }\end{array}$ & $\begin{array}{c}\text { Frequency } \\
\text { of uses/ } \\
\text { year }\end{array}$ & $\begin{array}{l}\text { Total } \\
\text { trips }\end{array}$ & $\begin{array}{c}\text { Taka/ } \\
\text { trip }\end{array}$ & $\begin{array}{c}\text { Packaging } \\
\text { cost, } \\
\text { (Tk./kg) }\end{array}$ \\
\hline Bamboo basket & 25 & 100 & $1 \mathrm{yr}$ & 3 & 3 & 33.33 & 1.32 \\
\hline Plastic crate & 20 & 350 & $3 \mathrm{yr}$ & 20 & 60 & 5.83 & 0.30 \\
\hline Wooden box & 20 & 350 & $2 \mathrm{yr}$ & 15 & 30 & 11.67 & 0.58 \\
\hline $\begin{array}{l}\text { CFB carton: } \\
513 \times 300 \times 240,7 \text { ply }\end{array}$ & 20 & 65 & 1 time & 1 & 1 & 65 & 3.25 \\
\hline $\begin{array}{l}\text { CFB carton: } \\
513 \times 300 \times 240,5 \text { ply }\end{array}$ & 20 & 58 & 1 time & 1 & 1 & 58 & 2.9 \\
\hline $\begin{array}{l}\text { CFB carton: } \\
400 \times 300 \times 300,7 \text { ply }\end{array}$ & 20 & 58 & 1 time & 1 & 1 & 58 & 2.9 \\
\hline $\begin{array}{l}\text { CFB carton: } \\
400 \times 300 \times 300,5 \text { ply }\end{array}$ & 20 & 50 & 1 time & 1 & 1 & 50 & 2.5 \\
\hline
\end{tabular}

\section{Conclusion}

Different sizes of corrugated fibre board carton and wooden box were designed, fabricated, and tested. CFB cartons were good condition for transportation of guava. The 7 ply of $513 \times 300 \times 240 \mathrm{~mm}$ and $400 \times 300 \times 300 \mathrm{~mm}$ cartons were better in respect of load bearing capacity. The holding capacity of them was about $20 \mathrm{~kg}$ of guava. The static load bearing capacity of 7 and 5 ply cartons were 90 and $70 \mathrm{~kg}$ for both the types, respectively. Guava packed and transported in wooden box was found in good condition amongst other packages, such as bamboo basket, corrugated fibre board carton and plastic crates. The highest shelf-life of guava was found in wooden box. Wooden box was found suitable packaging materials for transportation of guava in terms of freshness, shelf-life and packing cost. Packaging cost of CFB carton was higher than those of plastic crate and bamboo basket. Plastic crate and wooden box should be used for local market to transport the fruits. CFB carton may be used for export market or supper market. 


\section{References}

BBS (Bangladesh Bureau of Statistics). 2011. Statistical Yearbook of Bangladesh. Bangladesh Bureau of Statistics, Ministry of Planning, Government of the People's Republic of Bangladesh, Dhaka.

Elamine, M. A. 2006. Effect of polyethylene film lining and potassium permanganate on quality and shelf-life of banana fruits. M.Sc. Thesis, University of Khartoum, Sudan.

Elkashif, M. E., O. M. Elamin, S. A. Ali. 2005. Effect of packaging method and storage temperature on quality and storability of four introduced banana clones. Gezira Journal of Agricultural Science 3(2):185-195.

Francis, F. J. 1980. Colour quality evaluation of horticultural crops. Horticultural Science 15:58-59.

Han, J and J. M. Park. 2007. Finite element analysis of vent/hand hole designs for corrugated fibre boxes. Packaging Technology and Science 20:39-47.

Hunter, R. S. 1975. The meseasurment of appearance. Jone Wiley \& Sons, Inc., New York.

Lashley, D. 1984. Advances in postharvest technology and new technology in food production. Proceedings Seminar. St. Augustine (Trinidad Tobago). Pp.173-183.

Wills, R., B. McGlasson, D. Graham, D. Joyce. 1998. Postharvest: An Introduction to the Physiology and Handling of Fruit, Vegetables and Ornamentals. 4th Edition. CAB International, Wallingford Oxen 108 DE, U.K, 262.

Yahia E.M, and A. Ait-Oubahou. 2001. Training manual on postharvest physiology, technology and handlng of horticltural crops. Agricultural Research Management (ARMP-TA). IDA Credit \#2815-BD, Dhaka. 